\title{
Positive Crankcase Ventilation System
}

\author{
Gaoming Ding*
}

\author{
Jiandong College, CZJDU, Changzhou, China
}

\begin{abstract}
In this paper, we have studied the traditional Positive Crankcase Ventilation (PCV) valve equipment. Then we have improved the system by adding ventilation equipment. We have applied this kind of connection equipment on gas engine which has no PCV. This can determine the engine fuel-air ratio and make the engine get the best power performance, economical efficiency and emission behavior. Because emission amount is based on input air amount, so how to control the input air amount is the basis of the whole system. On the basis of traditional inlet manifold MVEM, we have considered the affection of PCV system, and we have simulated the actual input air process by getting improved module's input air amount and inlet manifold pressure parameters. So the fuel-air ratio precision can be increased greatly. We also have prompted some improving directions about traditional inlet manifold. So we can ensure that engine can get a compact structure and good response on the all operation states.
\end{abstract}

Index Terms: Crankcase; Ventilation; PCV system

(C) 2011 Published by MECS Publisher. Selection and/or peer review under responsibility of the Research Association of Modern Education and Computer Science.

\section{The function of PCV system}

When the engine is operating, some combustible mixture gas and exhaust gas can creep into crankcase by means of piston ring. So the engine oil will be diluted because of the mixture gas's coagulation. The exhaust gas's high temperature, acidity substances and water vapor can erode engine component and alchemize engine oil. On the other hand, the mixture gas also can increase the crankcase's inner pressure and temperature, and this can cause engine oil seepage, which forms engine malfunction. The function of PCV system is that it can protect environment by extracting the crankcase's mixture gas and exhaust gas and input fresh air which is helpful for engine air cylinder combustion. [1]

\footnotetext{
* Corresponding author.

E-mail address: hbxfqxyqxy_123@163.com
} 


\section{The principle of PCV system}

All the gas engines have crankcase ventilation equipment. There are two kinds of crankcase ventilation types: natural ventilation and positive ventilation. Fig.1 shows the first type. It is dependant on the back pressure which formed when automobile is running, so the crankcase's inner mixture gas can be extracted and fresh air can be entered by means of air cleaner and throttling valve at the exit of exhaust pipe. Because natural ventilation type is not good for environment, so the PCV system can be used on gas engine widely.

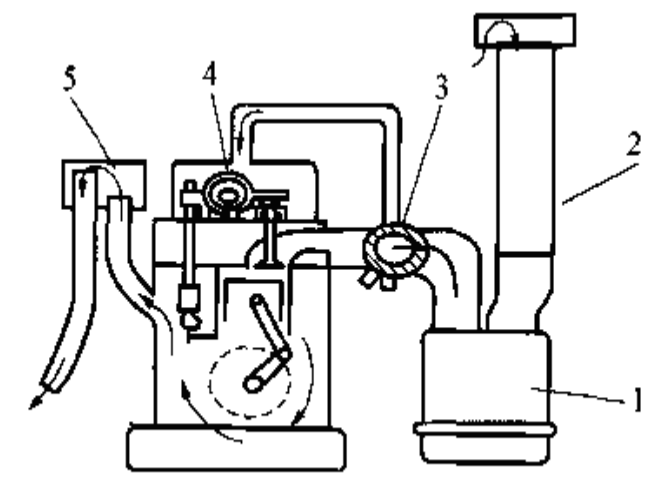

1.Air cleaner 2.Inlet pipe 3.Throttling valve 4.Valve shroud 5 Exhaust pipe

Fig. 1 Natural ventilation

Fig.2 shows the positive ventilation type. Positive ventilation can abstract crankcase's inner mixture gas into engine inlet pipe at proper time by means of engine inlet pipe's vacuum performance. So the mixture gas can get combustion again, which protects environment. Modern automobile engines almost all have used PCV system.

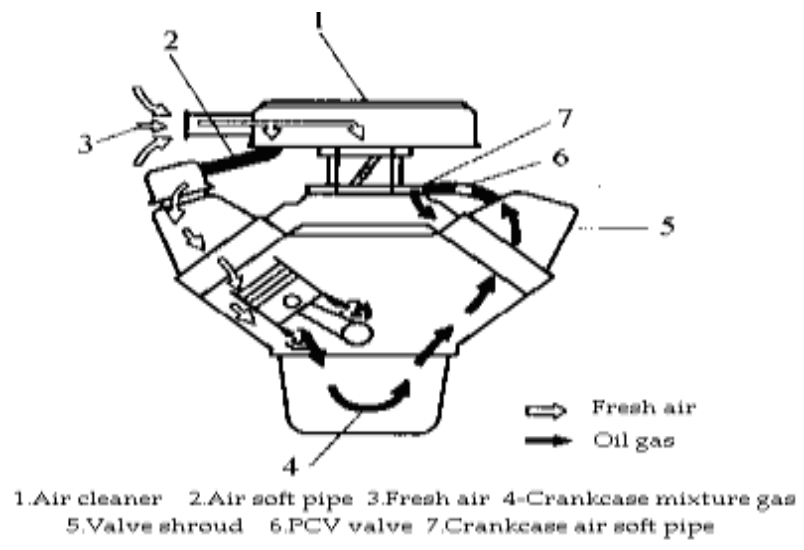

Fig. 2 Close positive ventilation of crankcase

When the engine is operating, the inlet pipe's vacuum will affect PCV valve, it makes fresh air come into air cylinder by means of air cleaner and air soft pipe, and then enter into crankcase by means of cylinder shroud. In crankcase, fresh air will be mixed in mixture gas, and then the mixed gas will enter into inlet pipe by means of air cylinder shroud and PCV valve. At last, the mixed gas will be combusted in engine.[2] 
The function of PCV valve is that it can adjust the crankcase inner gas amount automatically in accordance with engine's operation. PCV valve consists of PCV valve base, spring, cone valve and valve base. Fig.3 shows its structure.

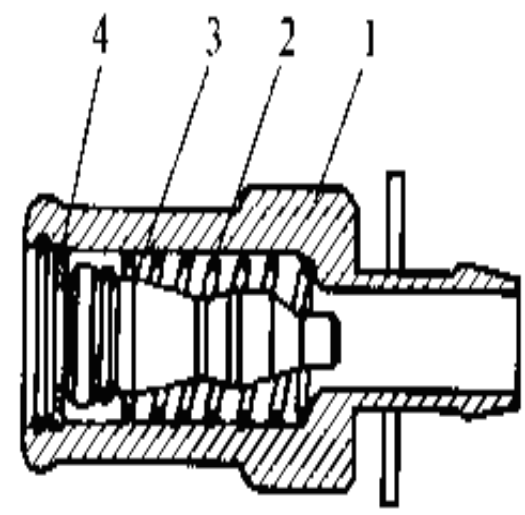

\section{PCV valve body 2 .Spring 3.Cone valve 4 Valve base}

Fig. 3 The structure of PCV valve

Fig.4 shows the principle of PCV valve.

- When engine is not operating, cone valve will cling to valve base because of the force of spring. This can close channel between crankcase and inlet manifold. Fig.4 (a) shows the structure.

- When engine is in the state of idle speed or reducing speed, the degree of vacuum of inlet pipe is big, which causes a little crack between cone valve and valve body. Fig.4 (b) shows the principle. Because when engine is in the state of idle speed or reducing speed, there is little mixture gas in the crankcase. So, although the degree of PCV valve's opening is small, it is adequate to abstract crankcase's inner mixture gas.

- When throttle valve opens more, the degree of inlet pipe vacuum is smaller than the state of idle speed. So the crack between cone valve and valve body will get big because of the spring's force. Fig.4(C) shows this. Because engine load will be bigger, so the crankcase's inner mixture gas will be more, so this can make all the crankcase's mixture gas be abstracted into inlet pipe.

- With the increasing of engine load, the degree of vacuum of inlet pipe will be small. Cone valve will leave valve body because of spring force, which increases the air flow amount of crankcase. Fig.4 (d) shows the structure. When the air amount reaches the maximal load, which ensures that crankcase can get fresh air.

- When inlet pipe is in the state of tamper, the inlet pipe pressure will increase, and cone valve falls back valve base, which can prevent tamper from entering into crankcase. When the cylinder wear is serious, there will be more mixture gas enters crankcase, and this can't make all the mixture gas enter inlet pipe in spite of the PVC valve has been in maximal opening. At this time, crankcase pressure will be increased, and some crankcase mixture gas will enter air cleaner by means of air soft pipe and flow into air cylinder with fresh air. 


\section{Example of positive crankcase ventilation system}

The positive crankcase ventilation system of Santana 2000GSi car AJR engine mainly consists of crankcase vent-pipe and PCV valve. The mixture gas in crankcase is abstracted into engine by means of crankcase's air soft pipe and PCV valve, which can't pollute environment. The main component of this kind of positive crankcase ventilation system is PCV valve. [3]

When the PCV valve ad its pipes are blocked, there are such errors as unstable idle speed, low idle speed and engine oil seepage may be produced. While PCV valve or its pipes are damaged, the engine maybe has unstable idle speed. The detail checking methods are:

- When the engine is in idle speed, we should pull out PCV valve. At this time, the rotation speed of engine will be increased 100r/min than before. Otherwise, this shows that PCV valve or its pipes are not well, we must clean or replace soft pipes.

- When the engine is in idle speed, we put thumb on the end of PCV valve and we should sense the vacuum force. If we don't feel the force, this means that there are some damages and we should clean or replace soft pipe.

- After we removing PCV valve, we can hear clatter when we vibrate it. Otherwise we should replace PCV valve.

\section{Improvement of positive crankcase ventilation system}

\subsection{Basic principles about the improvement of positive crankcase ventilation system}

In engine's positive crankcase ventilation system, there should be processing system which used to process crankcase exhaust gas. The exhaust mainly consists of incombustible fuel, gas, particle material and gaseous combustible material. All these exhaust gas should be abstracted into engine and then be combustible. So the positive crankcase ventilation system which used to process crankcase exhaust gas includes that:

We should fix Liquid filtering equipment which can be used to filter the exhaust gas from engine crankcase. And at least one kind of exhaust gas can be separated from crankcase exhaust materials. The positive crankcase ventilation is located under the filtering equipment, which used to adjust the pressure of the filtering equipment's crankcase exhaust materials.

We also should fix the necessary electric equipment, which should be lied under the positive crankcase ventilation and be used to transmit static charges to filtered positive crankcase ventilation materials before they be transmitted to engine's inlet part. The filtering equipment should include that: the shroud with one entrance and one exit, and the entrance should be connected with engine positive crankcase ventilation's exit, and the exit of shroud should be connected with engine positive crankcase ventilation's vacuum entrance. On the other hand, there is at least one obstruct component which is in the shroud. [4]

\subsection{Principle of improved exhaust control system}

Improved exhaust control system: Exhaust control system can control the amount of harmful gas in exhaust gas, the fuel vapor and the combustible mixture gas in crankcase. So the pollution which caused by automobile can be reduced greatly. Fig.5 shows the control system's principle. 


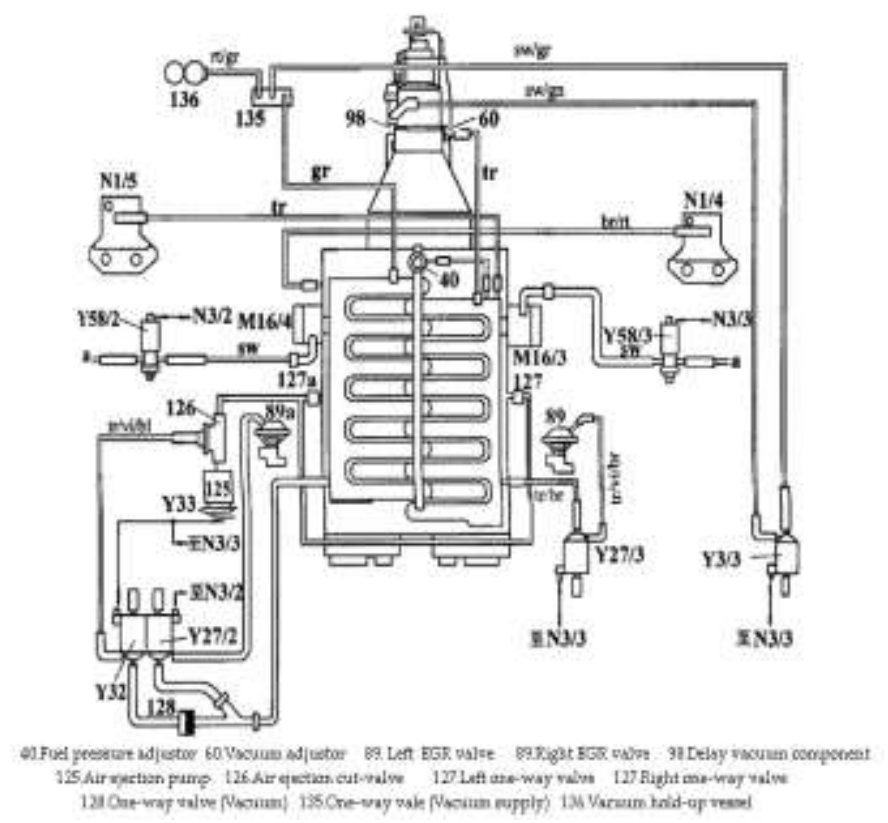

Fig. 5 Improved exhaust system

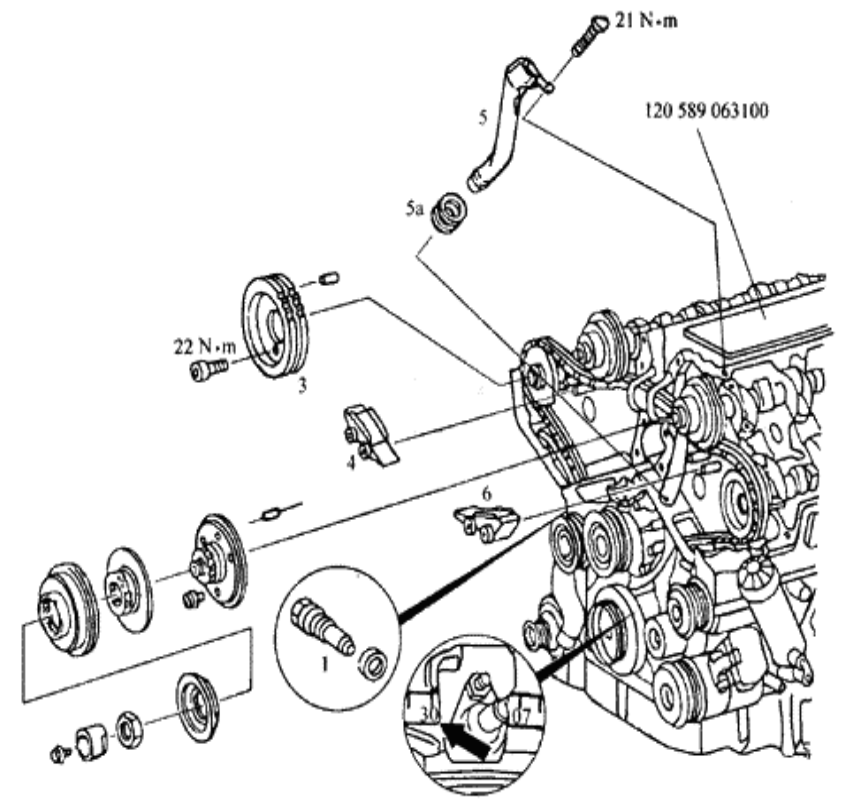

Fig. 6 Improved exhaust control system 


\subsection{Improving exhaust control system}

Secondary air ejection system: air ejection system supplies fresh air for the combusted exhaust gas, the oxidizing $\mathrm{CO}$ and $\mathrm{HC}$ compound and produces quantity of heat which used to help catalytic converter.

Catalytic converter: it can convert the harmful substances into $\mathrm{CO}_{2}$ and water effectively.

EVAP: fuel vapor is controlled by closed oil box ventilation system and carbon canister which is full activated carbon. Carbon canister can absorb fuel vapor. When engine is running, the valve is open, and the air and stored fuel vapor in carbon canister are all absorbed into engine.

EGR: EGR system can reabsorb the exhaust gas into inlet air system, which can reduce the temperature in firebox. So the nitrogen oxide can be reduced.

FR: in order to prevent fuel with lead from being filled, we have fixed oil filling pipe limitator. This can prevent heavy caliber compressor gun which is always used to fill fuel with lead from being put into oil box. The fuel with lead can cause the permanent pollution of oxygen sensor and catalytic converter.

PCV system: PCV system can prevent mixture gas from entering into atmosphere. PCV system can put exhaust gas into inlet air system by means of recycle system, and then be combusted.

\subsection{Principles}

Two independent EGR systems have been used in the engine, and every EGR valve has been fixed on the exhaust manifold closely. LH computer controls the exhaust gas by means of EGR valve. When the cooling water's temperature is higher than $65^{\circ} \mathrm{C}$ and the engine is in between the state of idle speed and full load, the selector valve is charged with electricity. After the EGR selector valve being open, the inlet manifold's vacuum is connected with EGR selector valve and the EGR valve is open. At this time, some part of exhaust gas from exhaust manifold flow into inlet manifold.

Fig.5 shows that the left EGR valve is connected with exhaust manifold of the tenth cylinder, and the exhaust gas flows into inlet manifold. Right EGR valve is connected with the fourth cylinder's exhaust manifold, and the exhaust gas flows into inlet manifold of left cylinders.

Fig.6 shows that the EGR selector valve is located on the exhaust manifold. LH computer controls exhaust recycles by means of EGR selector valve. When LH computer opens the circuit with selector valve, the selector valve will be open and the vacuum will be in EGR valve. [5]

\section{Conclusions}

The improved positive crankcase ventilation vent valve can get from the following measures. We have fixed a reducer on oil filling pipe, and the big point end of reducer is connected with the pipe, and the small point end of reducer is connected with positive crankcase ventilation vent valve. We also have put a carburetor heel block between carburetor and inlet air pipe. This kind of positive crankcase ventilation vent valve's connection equipment has been applied in the engine without fixing positive crankcase ventilation vent valve. It can determine the engine fuel-air ratio and make the engine get the best power performance, economical efficiency and emission behavior. Because emission amount is based on input air amount, so how to control the input air amount is the basis of the whole system. On the basis of traditional inlet manifold MVEM, we have considered the affection of PCV system, and we have simulated the actual input air process by getting improved module's input air amount and inlet manifold pressure parameters. So the fuel-air ratio precision can be increased greatly. We also have prompted some improving directions about traditional inlet manifold. So we can ensure that engine can get a compact structure and good response on the all operation states. 


\section{References}

[1] LI Ding-gen, LI Xiao-zhong, Study on Gasoline Intake Model Modification Based on PCV[J], VEHICLE ENGINE, 2009(1)

[2] ZHANG Bo, FU Wei-biao, Fuel Consumption Study on a Diesel Engine Fueled with Emulsified Fuel and Ethanol[J], JOURNAL OF COMBUSTION SCIENCE AND TECHNOLOGY, 2006 12(1)

[3] Li Qingfeng, Xiao Jin, Simulation of Two Stroke HCCI Free Piston Linear Alternator[J], TRANSACTIONS OF THE CHINESE SOCIETY FOR AGRICULTURAL MACHINERY, 2009 40(2)

[4] Xiao Chong, Zuo Zhengxing, Dynamic Simulation and Characteristic of Free Piston Generator[J], TRANSACTIONS OF THE CHINESE SOCIETY FOR AGRICULTURAL MACHINERY, 2009 40(2)

[5] Huang Fang, Application of PLC in marine diesel engine rate governor[J], JIANGSU SHIP, 2007 24(3) 